\title{
Angiosperms from rocky outcrops of Pedra do Elefante, Nova Venécia, Espírito Santo, Brazil
}

\author{
Nelson Túlio Lage Pena ${ }^{1,2}$ \& Anderson Alves-Araújo ${ }^{1}$
}

\begin{abstract}
We provide a floristic inventory of Angiosperms from rocky outcrops of the Área de Proteção Ambiental Pedra do Elefante, Espírito Santo, Brazil. Fieldwork was performed monthly from March/2015 to July/2016. A checklist with 302 species belonging to 219 genera and 74 families is provided. Bromeliaceae, Orchidaceae, Fabaceae, Euphorbiaceae, Apocynaceae, Asteraceae, Cactaceae, Convolvulaceae, Rubiaceae, Bignoniaceae and Cyperaceae are the richest families with around $50 \%$ of the listed species. One hundred forty seven species are exclusively rupicolous, $125 \mathrm{spp}$. exclusively terricolous, $26 \mathrm{spp}$. are epiphytes, and six species are found as both rupicolous and terricolous. Phanerophytes and chamaephytes were predominant life forms. Our results added 18 new records to the Espírito Santo state, indicated the occurrence of nine endemic species for the state and noticed that only 55 taxa of the total of species have threat assessments according to IUCN. Key words: Atlantic rainforest, floristic inventories, inselberg, neotropics.

\section{Resumo}

O objetivo deste trabalho foi realizar o inventário florístico das Angiospermas dos afloramentos rochosos da Área de Proteção Ambiental Pedra do Elefante, Espírito Santo, Brasil. Expedições de coleta foram realizadas mensalmente de março/2015 a julho/2016. Um total de 302 espécies pertencentes a 219 gêneros e 74 famílias foram encontradas. Bromeliaceae, Orchidaceae, Fabaceae, Euphorbiaceae, Apocynaceae, Asteraceae, Cactaceae, Convolvulaceae, Rubiaceae, Bignoniaceae e Cyperaceae são as famílias mais ricas com cerca de 50\% de representatividade das espécies listadas. Os táxons exclusivamente rupícolas são representados por 147 espécies enquanto $125 \mathrm{spp}$. São exclusivamente terrícolas, $26 \mathrm{spp}$. são epífitas e seis espécies são encontradas como tanto como rupícolas quanto terrícolas. As formas de vida predominantes foram fanerófitas e as caméfitas. Nossos resultados adicionaram 18 novos registros ao estado do Espírito Santo, indicaram a ocorrência de nove espécies endêmicas para o estado e indicam que apenas 55 táxons do total de espécies encontradas possuem avaliações de quanto às categorias de ameaça de acordo com a UICN.
\end{abstract}

Palavras-chave: Mata Atlântica, inventário florístico, afloramentos rochosos, neotrópicos.

\section{Introduction}

Rocky outcrops can be found mainly in tropical and subtropical regions of the world (Barthlott et al. 1993). Due to peculiarities in the floristic composition, they turned into spotlights in different parts of the world (Hurault 1963; Ibisch et al. 1995; Meirelles et al. 1999; Porembski et al. 1997). They are constituted by granite and/or gneiss composition, and are a remarkable component in the landscapes (Porembski \& Barthlott 2000). The lack of continuous soil coverage is an important factor that induces environmental conditions such as high rates of sun exposition and evaporation, leading to specific adjustments and thereby generating a very distinct species composition (Porembski 2000).

In Brazil, the extra-Amazonian rocky outcrops that exhibit higher elevations may be found in the South and Southeast regions with special attention to the Serra do Mar, the Serra Geral, the Serra da Mantiqueira, and the Cadeia do Espinhaço (Oliveira-Filho et al. 2013). With increasing altitude and peculiar topography, rocky outcrops have great

\footnotetext{
${ }^{1}$ Universidade Federal do Espírito Santo, Prog. Pós-graduação em Biodiversidade Tropical - PPGBT/UFES, Rod. BR-101 Norte, Km 60, Bairro Litorâneo, 29932-900, São Mateus, ES, Brazil.

${ }^{2}$ Author for correspondence: penatulio@gmail.com
} 
diversity of habitats and native vegetation reflects directly to this heterogeneity, forming mosaics with high levels of endemism (Porembski et al. 1997; Oliveira-Filho et al. 2013).

Espírito Santo is one of the richest states in Brazil when considering Angiosperm diversity. It possesses 6,364 recorded taxa (Dutra et al. 2015) which represents around $32 \%$ of the species from the Atlantic Rainforest Domain (BFG 2015). Such richness may be easily treated as underestimated, especially by the lack of information in poorly sampled areas and fairly low number of available taxonomic studies (Dutra et al. 2015).

The floristic knowledge in ES were improved by studies conducted in the last decades (e.g., Peixoto \& Gentry 1990; Fabris \& César 1996; Pereira \& Zambom 1998; Pereira et al. 1998; Pereira \& Araújo 2000; Assis et al. 2004; Fraga et al. 2007; Esgario et al. 2009; Fabris \& Peixoto 2013; Chagas et al. 2014; Saiter \& Thomaz 2014; Sarnaglia Junior et al. 2014; Pertele et al. 2015; Dutra et al. 2015; Luber et al. 2016; Souza et al. 2016). These studies, however, included a few rocky outcrops of the state. Therefore, data regarding native and adapted species from rocky outcrops from the State are scarce. To achieve a fair comprehension aiming conservation of this very unique vegetation, floristics and comparison analysis are extremely important (Caiafa \& Silva 2005).

Low sampling efforts, habitat loss for many reasons (as cattle raising, fire and granite exploration), and unauthorized collection of plants cause negative impacts on the preservation of the rocky outcrops native vegetation, and affect the diversity of species in the Northern Espírito Santo. Thus, the objective of this study is to identify the Angiosperms flora from the rocky outcrops of the Área de Preservação Ambiental Pedra do Elefante, Nova Venécia, Espírito Santo, Brazil.

\section{Material and Methods}

\section{Study site}

The Área de Preservação Ambiental Pedra do Elefante (PE) belongs to the Nova Venécia municipality, Northwestern Espírito Santo state (ES), Brazil (1846’30’S, 40²7’42W) (Fig. 1).

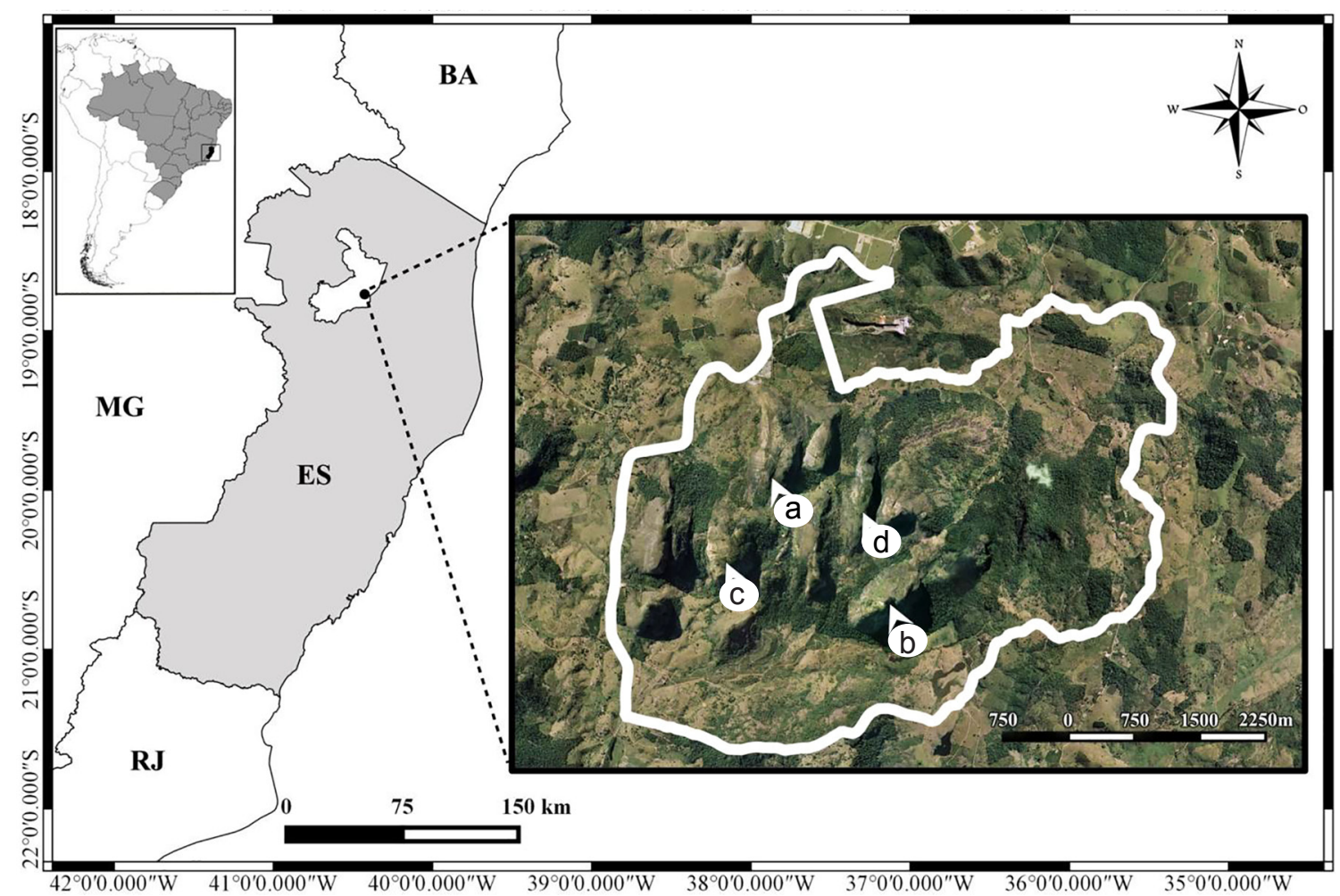

Figure 1 - Location map of APA Pedra do Elefante, Espírito Santo, Brazil - a. Pedra do Elefante rocky outcrop; b. Pedra da Dona Ecila (da Torre) rocky outcrop; c. rocky outcrop to the left to Pedra do Elefante rocky outcrop; d. rocky outcrop to the right to Pedra do Elefante rocky outcrop. 
It has $2,562,31$ ha with granitic rocky outcrops ranging 50-500 above sea level and associated to slope forests. Vegetation type is classified as Seasonal Semi-deciduous Submontane forest and is entirely inserted in the Atlantic Rainforest domain (IBGE 2012). Temperature and annual rainfall averages are $25^{\circ} \mathrm{C}$ and $800 \mathrm{~mm}$, respectively (INCAPER 2016).

The study encompassed four rocky outcrops (Fig. 2a-d): Pedra do Elefante (1845'59”S, $40^{\circ} 27^{\prime} 24,8^{\prime \prime}$ ) (Fig. 2a); Pedra da Dona Ecíla (da Torre) $\left(18^{\circ} 46^{\prime} 57,9^{\prime \prime} \mathrm{S}, 40^{\circ} 26^{\prime} 46,5^{\prime \prime} \mathrm{W}\right)$ (Fig. 2b); Pedra to the left of Pedra do Elefante (18'46'40's, $40^{\circ} 27^{\prime} 46,6^{\prime \prime} \mathrm{W}$ ) (Fig. 2c); and Pedra to the right of Pedra do Elefante $\left(18^{\circ} 46^{\prime} 9,6^{\prime}\right.$ 'S, 40 $26^{\prime}$ '51,6”W) (Fig. 2d). They were chosen based on accessibility and presence of remaining native vegetation criteria. This work considers as start point of sampling those with very clearly exposed rock areas and shallow soils from the bottom to the top of the rocky outcrops.
Sampling and general information

Sampling expeditions were carried out monthly from March/2015 to July/2016. Fertile specimens exclusively from the rocky outcrops were collected randomly and processed according to usual methods in plant taxonomy (Bridson \& Forman 1998). All collected samples are deposited at VIES herbarium (Thiers, continuously updated) and family circumscriptions follow APG IV (2016).

Additional data from previously collected samples were gathered from JABOT - Banco de Dados da Flora Brasileira (2016). Only specimens with complete environmental information (locality and substrate data obtained from exsiccate labels) were included. Author names and specific epithets were confirmed after consulting The International Plant Names Index (IPNI 2016).

Only taxa from rocky outcrops were gathered and classified as: (a) rupicolous (i.e., organisms fixed directly onto the rock, solitary or in vegetation
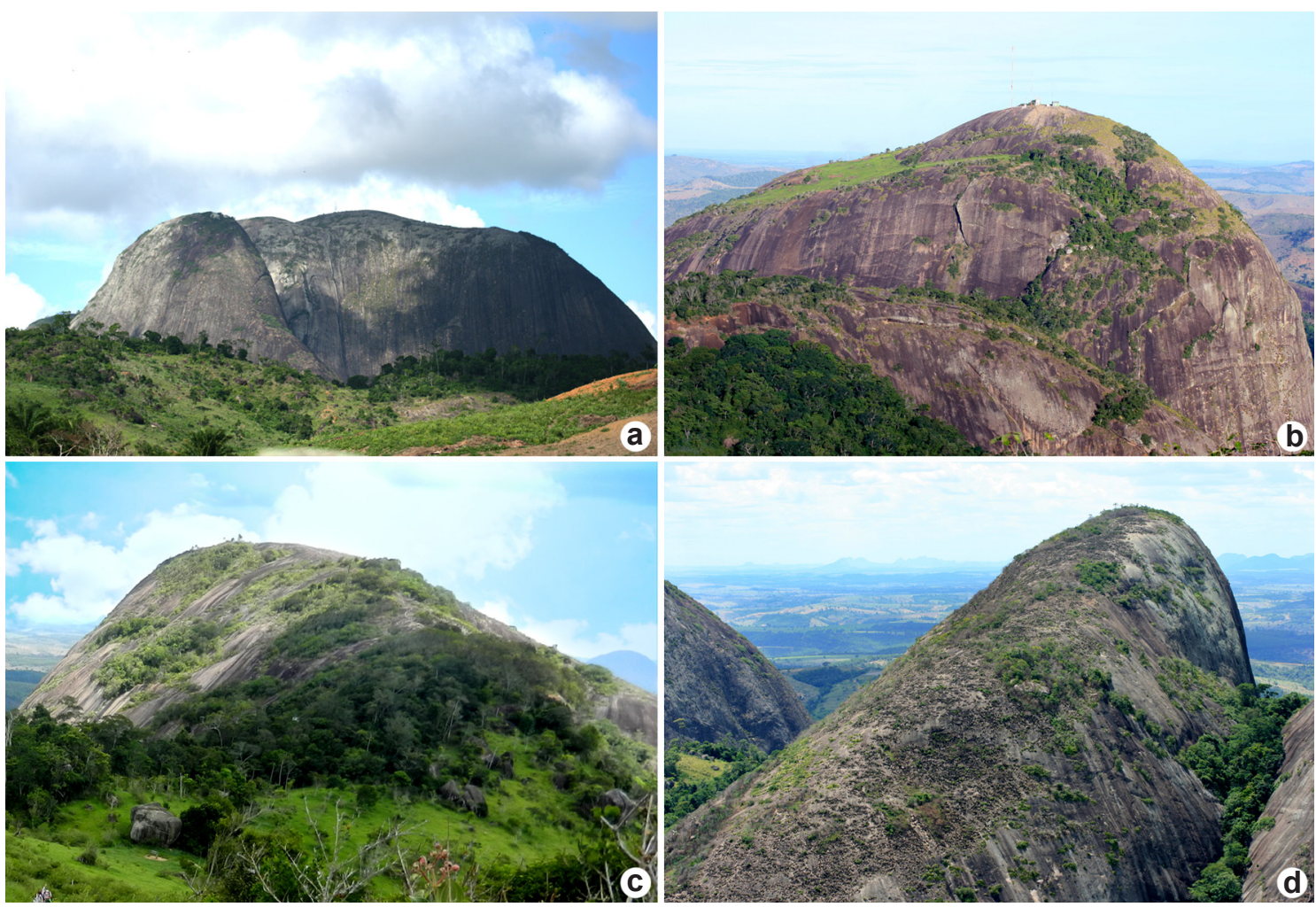

Figure 2 - Rocky outcrops shown in APA Pedra do Elefante, Espírito Santo, Brazil - a. Pedra do Elefante rocky outcrop; b. Pedra da Dona Ecila (da Torre) rocky outcrop; c. rocky outcrop to the left to Pedra do Elefante rocky outcrop; d. rocky outcrop to the right to Pedra do Elefante rocky outcrop. 
islands essentially formed by herbaceous species); (b) terricolous (i.e., organisms occurring on shallow soils in vegetation islands essentially formed by shrubs, treelets or trees species); and (c) epiphytes (i.e., Plants that use as support organisms that occur on shallow soils in vegetation islands essentially formed by shrubs, treelets or trees species). Life forms were based on Raunkiaer's (1934) and the species conservation statuses were consulted in IUCN (based on CNCFlora 2017). The first records for ES were assessed using Flora do Brasil 2020 $(<\mathrm{http}$ //floradobrasil.jbrj.gov.br/>).

\section{Results}

A total of 302 species belonging to 219 genera and 74 families were recorded from PE rocky outcrops (see supplementary material $<$ https://figshare.com/s/8bb98b0d9e36e045befa $>$ ). Bromeliaceae (24 spp.), Orchidaceae and Fabaceae (19 spp., each), Euphorbiaceae (18 spp.), Apocynaceae (14 spp.), Asteraceae, Cactaceae, Convolvulaceae and Rubiaceae (10 spp., each), Bignoniaceae and Cyperaceae (eight spp., each) are the richest families with around $50 \%$ of the listed species (Fig. 3). On the other hand, $32.5 \%$ of the recorded families (24 families) are represented by a single taxon.

Peperomia Ruiz \& Pav. (Piperaceae) with seven spp., Acianthera Scheidw. (Orchidaceae), Mandevilla Lindl. (Apocynaceae), and Tillandsia L. (Bromeliaceae) with five spp. (each), Aechmea Ruiz \& Pav. (Bromeliaceae), Borreria G.Mey. (Rubiaceae), and Solanum L. (Solanaceae) with four spp. (each) are the most representative genera regarding species number. Besides, they together totaled around $20 \%$ of the recorded taxa.

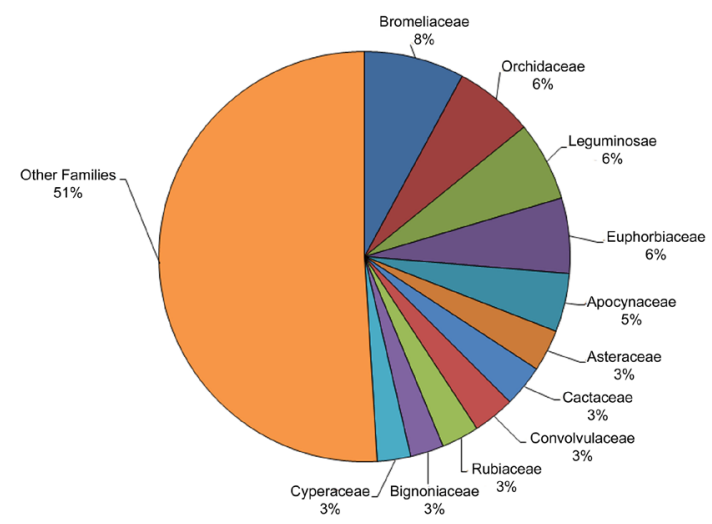

Figure 3 - Representation of the richest families from APA Pedra do Elefante, Espírito Santo, Brazil.
One hundred fourty seven species are exclusively rupicolous, followed by $125 \mathrm{spp}$. exclusively terricolous, epiphytes with $26 \mathrm{spp}$., and six species are found as both rupicolous and terricolous: Handroanthus selachidentatus (A.H. Gentry) S.Grose (Bignoniaceae); Dichorisandra hexandra (Aubl.) C.B. Clarke, D. thyrsiflora J.C. Mikan (Commelinaceae); Aosa parviflora (Schrad. ex DC.) Weigend (Loasaceae); Prescottia plantaginifolia Lindl. ex Hook. (Orchidaceae); and Randia armata (Sw.) DC. (Rubiaceae).

Amongst exclusively rupicolous species (Fig. 4), Bromeliaceae (14 spp.), Euphorbiaceae (11 spp.), Fabaceae (eight spp.), Cactaceae, Cyperaceae and Melastomataceae (seven spp., each) have the highest values of richness and the most common life forms, in this order, are chamaephytes (72 spp.), phanerophytes (70 spp.), hemicryptophytes [Anthurium jilekii Schott, Anthurium parasiticum (Vell.) Stellfeld, Philodendron edmundoi G.M. Barroso (Araceae) and Utricularia subulata L. (Lentibulariaceae)]; and Geophytes (Hippeastrum sp. - Amaryllidaceae).

Exclusively terricolous species (Fig. 5a-f) are represented by Fabaceae (11 spp.), Convolvulaceae (nine spp.), Apocynaceae (spp.), Euphorbiaceae (spp.), and Bignoniaceae (five spp.) as the richest families. On the contrary compared to the rupicolous plants, the most common life forms are phanerophytes (94 spp.), followed by chamaephytes (27 spp.), and the Hemicryptophyte species: Tridax procumbens L. (Asteraceae). One single taxon, Philodendron pedatum (Hook) Kunth (Araceae), was registered as both rupicolous and terricolous and is an hemiepiphyte plant.

Epiphytes (Fig. 5h) are represented by species of Orchidaceae (10 spp.), Bromeliaceae and Piperaceae (six spp., each), Cactaceae (three spp.), and Araceae [Lepismium cruciforme (Vell.) Miq.]. They are usually found occurring associated to the vegetation islands formed essentially by shrubs, treelets and trees on the shallow soils. The predominant life forms were, in general, phanerophytes and chamaephytes, representing $54 \%$ and $33 \%$, respectively (Fig. 6).

Eighteen new records for Espírito Santo are listed below (see supplementary material $<$ https://figshare.com/s/8bb98b0d9e36e045befa >): Alternanthera bahiensis Pedersen (Amaranthaceae); Cereus hildmannianus K.Schum. subsp. hildmannianus (Cactaceae); Kielmeyera coriacea Mart. \& Zucc. (Calophyllaceae); Maytenus ilicifolia Mart. ex Reissek (Celastraceae); Evolvulus 

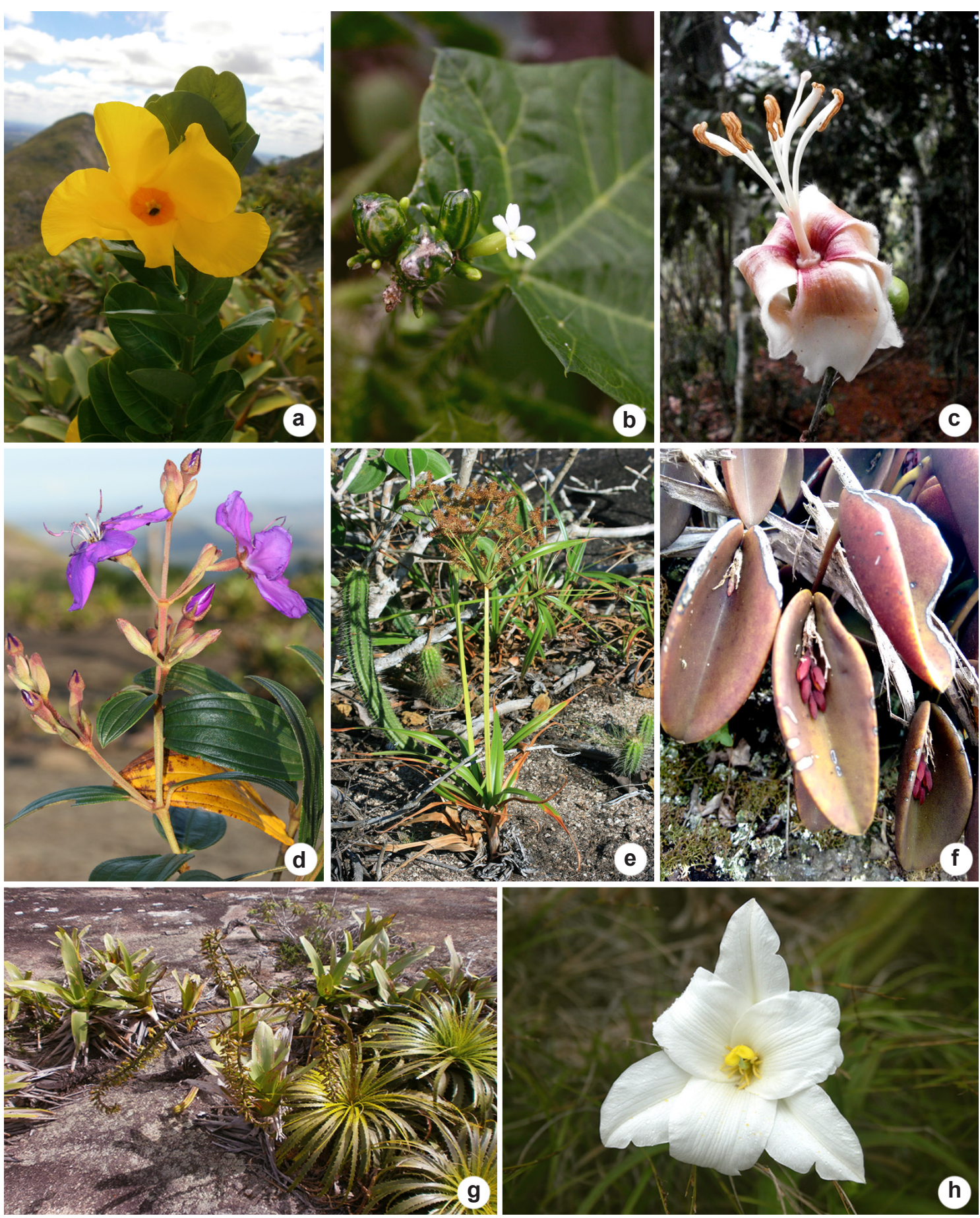

Figure 4 - Rupicolous species from APA Pedra do Elefante - a. Mandevilla fistulosa (Apocynaceae); b. Cnidoscolus urentissimus (Euphorbiaceae); c. Ceiba erianthos (Malvaceae); d. Pleroma fissinervia (Melastomataceae); e. Cyperus pohlii (Cyperaceae); f. Acianthera limae (Orquidaceae); g. Encholirium horridum (Bromeliaceae); h. Vellozia candida (Velloziaceae). 

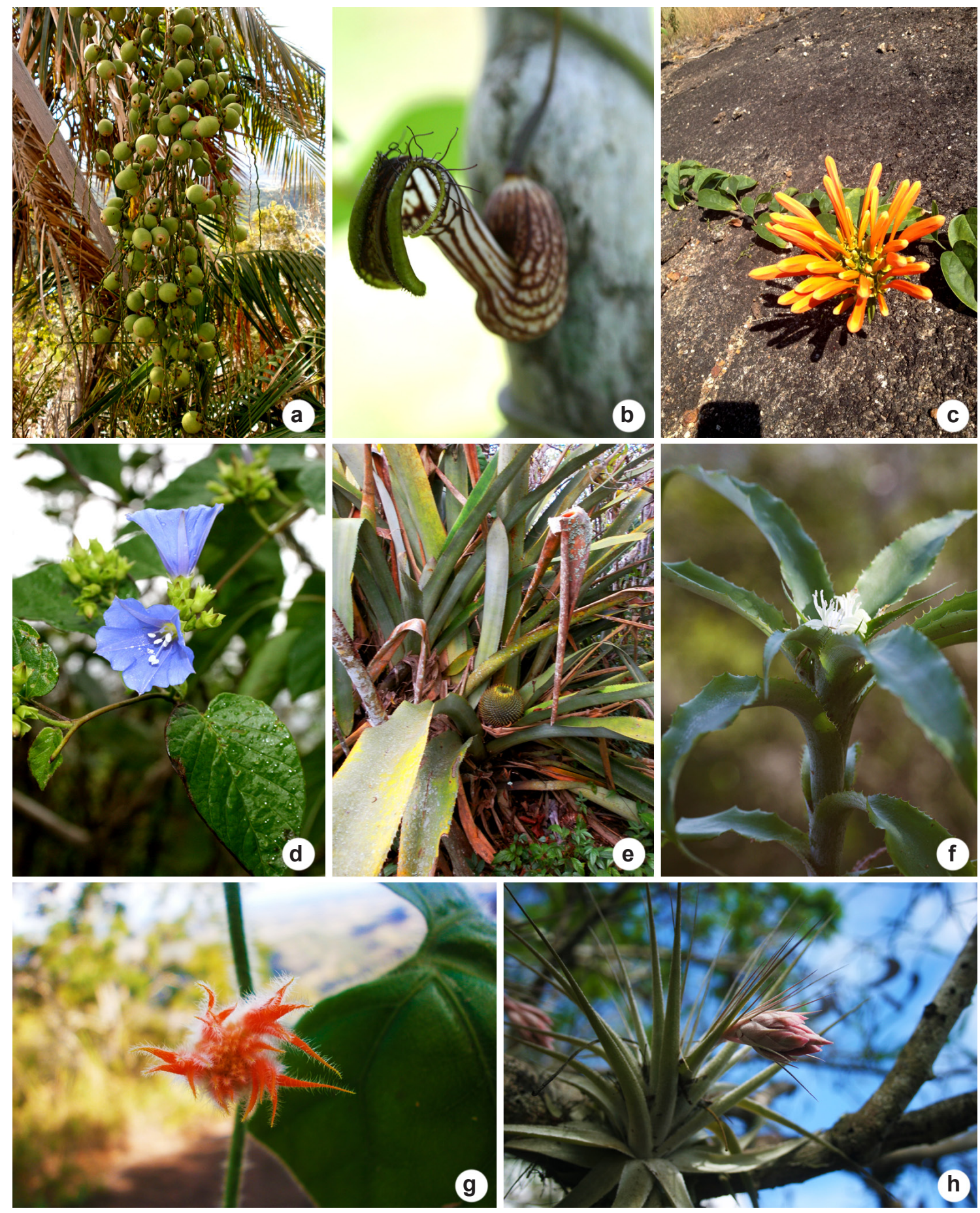

Figure 5 - Terrestrial and epiphyte species from APA Pedra do Elefante rocky outcrops - a. Syagrus pseudococos (Arecaceae); b. Aristolochia gracilipedunculata (Aristolochiaceae); c. Pyrostegia venusta (Bignoniaceae); d. Jacquemontia martii (Convolvulaceae); e. Aechmea saxicola (Bromeliaceae); f. Cryptanthus venecianus (Bromeliaceae); g. Gurania eriantha (Cucurbitaceae); h. Tillandsia gardneri (Bromeliaceae). 
lithospermoides Mart., Ipomoea bahiensis Willd. ex Roem. \& Schult. (Convolvulaceae); Fevillea bahiensis G. Rob. \& Wunderlin, Momordica charantia L. (Cucurbitaceae) [naturalized]; Cnidoscolus urens var. neglectus (Pohl) Lourteig, Manihot leptopoda (Müll.Arg.) D.J.Rogers \& Appan, Stillingia argutedentata Jabl. (Euphorbiaceae); Erythroxylum nummularia Peyr. (Erythroxylaceae); Anadenanthera peregrina var. falcata (Benth.) Altschul, Senna oblongifolia (Vogel) H.S.Irwin \& Barneby (Fabaceae); Strychnos brasiliensis Mart. (Loganiaceae); Sida cerradoensis Krapov. (Malvaceae); Cissampelos pareira L. (Menispermaceae); Portulaca pilosa L. (Portulacaceae); and Borreria virgata Cham. \& Schltdl. (Rubiaceae).

Nine endemic taxa were registered: Philodendron stenolobum E.G.Gonç. (Araceae); Begonia aguiabrancensis L.Kollmann (Begoniaceae); Alcantarea trepida Versieux \& Wand., Cryptanthus venecianus Leme \& L.Kollmann (Bromeliaceae); Kielmeyera rupestris Duarte (Calophyllaceae); Clusia spiritusanctensis G.Mariz \& B.Weinberg (Clusiaceae); Merianthera parvifolia R.Goldenb., Fraga \& A.P. Fontana (Melastomataceae); Cattleya hoehnei Van den Berg (Orchidaceae); and Peperomia ciliatocaespitosa Carv.-Silva \& E.F.Guim (Piperaceae).

Only 55 species from the list are assigned under IUCN categories (based on CNCFlora 2016): Least Concern - LC (40 spp.); Near Threatened NT [Handroanthus selachidentatus (A.H. Gentry) S.Grose (Bignoniaceae), Rodriguezia obtusifolia (Lindl.) Rchb.f. (Orchidaceae)]; Vulnerable - VU [Chrysophyllum splendens Spreng. (Sapotaceae), Orthophytum foliosum L.B.Sm. (Bromeliaceae), Syagrus ruschiana (Bondar) Glassman

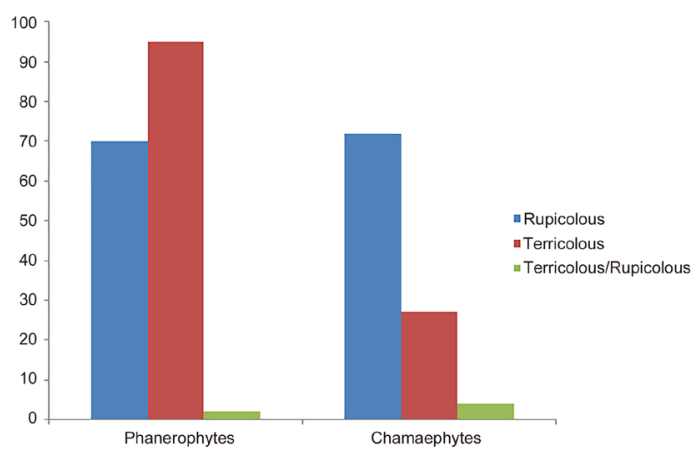

Figure 6-Representation of the predominant life forms from APA Pedra do Elefante rocky outcrops, Espírito Santo, Brazil.
(Arecaceae)]; Endangered - EN [Cololobus rupestris (Gardner) H.Rob. (Asteraceae), Begonia ibitiocensis E.L.Jacques \& Mamede (Begoniaceae), Encholirium cf. gracile L.B.Sm. E. horridum L.B.Sm. (Bromeliaceae), Sinningia aghensis Chautems (Gesneriaceae), Stigmaphyllon crenatum C.E.Anderson (Malpighiaceae), Cattleya hoehnei Van den Berg, Pseudolaelia citrina Pabst (Orchidaceae), and Solanum sycocarpum Mart. \& Sendtn. (Solanaceae)]; and Critically endangered - CR [Kielmeyera rupestris Duarte (Calophyllaceae)].

\section{Discussion}

Results provided different values for species richness against previously investigations carried out in Brazil (e.g., França et al. 1997; Meirelles et al. 1999; Caiafa \& Silva 2005, 2007; Conceição et al. 2007; Araújo et al. 2008; Esgario et al. 2009; Gomes \& Alves 2009, 2010; Gomes et al. 2011; Gomes \& Sobral-Leite 2013). This could be explained by methodological aspects adopted. In general, studies which bring vegetation structural analysis show lower species richness (e.g., Kurtz \& Araújo 2000; Thomas et al. 2009). However, considering only studies with similar sampling methods, the number of species increases from $15 \%$ (e.g., França et al. 1997) to around 30\% (e.g., Araújo et al. 2008). Regarding Atlantic Rainforest Domain, investigations such as Caiafa \& Silva (2005), Esgario et al. (2009), and Gomes \& Sobral-Leite (2013) indicated Angiosperms richness for different areas with 75, 172, and 138 species, respectively, Elucidating that depending on the type of floristic compositions present in the area under study, different taxonomic richness will be presented.

The most representative families in $\mathrm{PE}$ reflect a floristic composition pattern for rocky outcrops found both in the Brazilian Atlantic forest and in the Northeastern semi-arid. Compared to the other floras, it was noticed there is an alternation among the top six richest families, for instance: Asteraceae, Bromeliaceae, Cyperaceae, Euphorbiaceae, Fabaceae, and Orchidaceae (e.g., Meirelles et al. 1999; Conceição et al. 2007; Esgario et al. 2009; Gomes \& Alves 2009, 2010; Gomes \& SobralLeite 2013).

Porembski \& Barthlott (1997) highlight some Angiosperm families as the most commonly found for rock outcrops in South America with great specific diversity like Melastomataceae, Orchidaceae, Cactaceae, and Bromeliaceae. Melastomataceae, however, is represented 
only by seven species in PE, which does not corroborate with the authors. On the contrary, the significant number of families represented here by a single species $(32.5 \%)$ indicates that PE fits in a characteristic pattern of high diversity areas (Ratter et al. 2003).

Taxonomic groups typically cited as occurring on rocky outcrops like Alstroemeriaceae, Droseraceae and Eriocaulaceae were not found occurring in PE. This could be likely associated to the lack of water pools on the inselberg surface or even to the severe dry season that lasts over three years in the region. But, it is not a surprise when considered the stated by Porembski (2007), where the author asserts that vegetation of inselbergs in southeastern Brazil is extremely rich in dry resistant perennial species whereas annuals are relatively rare.

There is also alternation amongst top six richest genera when compared to the lists made by Gomes \& Alves $(2009 ; 2010)$ and Gomes \& Sobral-Leite (2013): Acianthera (Orchidaceae), Aechmea and Tillandsia (Bromeliaceae), Erythroxylum P.Browne (Erythroxylaceae), Ipomoea L. (Convolvulaceae) and Mandevilla (Apocynaceae). Peperomia (Piperaceae) stands out as the richest genus in PE and this could be explained by considering terricolous species. Six out seven Peperomia species found are epiphytes and depend on the shrubs and trees for fixation.

High values of rupicolous species richness (147 spp.) were expected, and this life form represents almost half (48\%) of the recorded taxa. They have adaptive strategies such as water accumulation in pools on leaf sheaths, specialized trichomes, and presence of bulbs or pseudobulbs, which turn them able to survive in this kind of environmental conditions (Porembski \& Barthlott 1997). Vegetation islands formed by herbaceous species or the "monocotyledonous mats", according to Barthlott et al. (1993), are visually frequent in PE, especially those formed by Alcantarea trepida Versieux \& Wand. This species is easily seen and usually has the majority of rupicolous species associated to it (personal observation).

Terricolous plants totaled $41 \%$ of the registered species in PE (126 spp.) and they correspond to those taxa which form shrubby/tree vegetation islands. They occur on shallow soils and/or on rock fissures that could accumulate water and organic soils. Those vegetation islands are constituted by important landscape elements [Kielmeyera coriacea Mart. \& Zucc. (Calophyllaceae), Anadenanthera peregrina var. falcata (Benth.) Altschul (Fabaceae), and Myrsine coriacea (Sw.) R.Br. ex Roem. \& Schult. (Primulaceae)], which might be colonized by epiphytes and hemi-epiphytes species.

Even found associated to terricolous plants, some epiphytes species have adaptive strategies which make them able to colonize rocks (Benzing 1987). Epidendrum L. species (Orchidaceae) are thought to be one of them. For instance, Epidendrum campaccii Hágsater \& L.Sánchez was found occurring both on monocotyledonous mats and on shrub/tree vegetation islands in the studied site. The same was observed by Gomes and Sobral-Leite (2013) with other two species: Epidendrum cinnabarinum Salzm. ex Lindl. and Epidendrum rigidum Jacq.; where both could be found in the canopy of tropical forests. Although epiphytes species were not mentioned by Raunkiaer (1934), some studies bring this information considering them as phanerophytes.

In general, phanerophytes was the predominant life form followed by Chamaephytes in the analyzed site. Although chamaephytes is the second most important life form, they are the group who covers most of the area. Almost the same was found by Gomes and Alves (2010), with phanerophytes in the first place but therophytes rising up as the second group in two sites in the semi-arid region of Brazil. Additionally, Gomes and Sobral-Leite (2013) asserted the inverse order, in two different areas in the Atlantic forest of the Northeastern Brazil, with therophytes as the most important life form followed by phanerophytes. The authors inferred that therophytes are rarely restricted to rupicolous environments, with few exceptions. Yet, floristic composition likely underwent interferences by the surrounding forests (Gomes \& Sobral-Leite 2013). Our results corroborate the stated by Porembski \& Barthlott (1997) where they assigned phanerophytes as the most representative group in South America, whereas therophytes are less important.

New records and presence of endemic species in PE is likely related to the singularities of floristic composition from rocky outcrops in the Northern ES. Our results add new records to the listed by Dutra et al. (2015) extending the known geographic distribution for some taxa, including those widely distributed in Brazil but not previously cited as occurring in ES, for instance: Anadenanthera peregrina var. falcata 
(Benth.) Altschul, Senna oblongifolia (Vogel) H.S.Irwin \& Barneby (Fabaceae), Cissampelos pareira L. (Menispermaceae), Cnidoscolus urens var. neglectus (Pohl) Lourteig (Euphorbiaceae), Ipomoea bahiensis Willd. ex Roem. \& Schult. (Convolvulaceae), Kielmeyera coriacea Mart. \& Zucc. (Calophyllaceae), Momordica charantia L. (Cucurbitaceae) [naturalized], Portulaca pilosa L. (Portulacaceae), Sida cerradoensis Krapov. (Malvaceae), and Strychnos brasiliensis Mart. (Loganiaceae). In addition, investigating areas like PE might reveal taxonomic novelties, e.g., Cryptanthus venecianus Leme \& L.Kollmann (Bromeliaceae) (Leme et al. 2010), Erythroxylum sp. nov. (Erythroxylaceae) (James L. Costa Lima, personal communication) and Pseudobombax sp. nov. (Malvaceae) (Jefferson Sobrinho, personal communication). Moreover, that region is known by higher levels of diversity and endemism found in the Atlantic Forest (Dutra et al. 2015).

Several human activities such as cattle raising, fire and granite exploration has increased dramatically on rocky outcrops, causing habitat loss and sometimes irreversible damage to their vegetation. Facing our results (high number of species, new records to the State and the record of endemic species), performing regional inventories is highly recommended to improve the quality of the knowledge and consequently the efforts for conservation of rocky outcrops vegetation.

\section{Acknowledgements}

We are grateful to Fundação de Amparo à Pesquisa e Inovação do Espírito Santo - Fapes for fellowship support to the first author. To IEMA and to the staff of Área de Proteção da Pedra do Elefante (Gilcemar Santana Pereira) for all support and collaboration. Also, to Dona Ecila and family for all support. To CEUNES/UFES for logistic support and all drivers. And finally, to the ad hoc reviewers for making this paper better.

\section{References}

APG IV - The Angiosperm Phylogeny Group (2016) An update of the Angiosperm Phylogeny Group classification for the orders and families of flowering plants. Botanical Journal of the Linnean Society 181: 1-20.

Araújo FS, Oliveira RF \& Lima-Verde LW (2008) Composição, espectro biológico e síndromes de dispersão da vegetação de um inselbergue no domínio da caatinga, Ceará. Rodriguésia 59: 659-671.
Assis AM, Thomaz LD \& Pereira OJ (2004) Florística de um trecho de restinga no município de Guarapari, Espírito Santo, Brasil. Acta Botanica Brasilica 18: 191-201.

Barthlott W, Gröger A \& Porembski S (1993) Some remarks on the vegetation of tropical inselbergs: diversity and ecological differentiation. Biogéographica 69: 105-124.

Benzing DH (1987) Vascular epiphytism: taxonomy participation and adaptative diversity. Annals of the Missouri Botanical Garden 74: 183-204.

BFG - The Brazil Flora Group (2015) Growing knowledge: an overview of seed plant diversity in Brazil. Rodriguésia 66: 1085-1113.

Bridson D \& L Forman (1998) The herbarium handbook. Royal Botanic Gardens, Richmond. 346p.

Caiafa AN \& Silva AF (2005) Composição florística e espectro biológico de um campo de altitude no Parque Estadual da Serra do Brigadeiro, Minas Gerais - Brasil. Rodriguésia 56: 163-173.

Chagas AP, Peterle PL, Thomaz LD, Dutra VF \& Valadares RT (2014) Leguminosae-Caesalpinioideae do Parque Estadual Paulo César Vinha, Espírito Santo, Brasil. Rodriguésia 65: 99-112.

CNCFlora (2016) Lista vermelha da flora brasileira versão 2016.1 Centro Nacional de Conservação da Flora. Available at <http://cncflora.jbrj.gov.br/ portal $>$. Access on 31 May 2017.

Conceição AA, Giulietti AM \& Meirelles ST (2007) Ilhas de vegetação em afloramentos de quartzito-arenito no Morro do Pai Inácio, Chapada Diamantina, Bahia, Brasil. Acta Botanica Brasilica 21: 335-347.

Dutra VF, Alves-Araújo A \& Carrijo TT (2015) Angiosperm checklist of Espírito Santo: using electronic tools to improve the knowledge of an Atlantic Forest biodiversity hotspot. Rodriguésia 66: 1145-1152.

Esgario CP, Fontana AP \& Silva AG (2009) A flora vascular sobre rocha no Alto Misterioso, uma área prioritária para conservação da Mata Atlântica no Espírito Santo, Sudeste do Brasil. Natureza on line 7: 80-91.

Fabris LC \& César O (1996) Estudos florísticos em uma mata litorânea no sul do estado do Espírito Santo. Boletim do Museu de Biologia Mello Leitão (nova série) 5: 15-46.

Fabris LC \& Peixoto AL (2013) Sapotaceae das restingas do Espírito Santo, Brasil. Rodriguésia 64: $263-283$.

Flora do Brasil 2020 [em construção] Jardim Botânico do Rio de Janeiro. Available at < http:// floradobrasil.jbrj.gov.br/ > . Access on 31 May 2017.

Fraga CN, Simonelli M \& Fernandes HQB (2007) Metodologia utilizada na elaboração da lista da flora ameaçada de extinção no Espírito Santo. In: Fraga CN \& Simonelli M (eds.) Espécies da flora ameaçadas de extinção no estado Espírito Santo. IPEMA, Vitória. Pp. 59-72. 
França F, Melo E \& Santos CC (1997) Flora de inselbergs da região de Milagres, Bahia, Brasil: I. Caracterização da vegetação e lista de espécies de dois inselbergs. Sitientibus 17: 163-184.

Gomes P \& Alves M (2009) Floristic and vegetational aspects of na inselberg in the semi-arid region of northeast Brazil. Edinburgh Journal of Botany 66: 329-346.

Gomes P \& Alves M (2010) Floristic diversity of two crystalline rocky outcrops in the Brazilian northeast semi-arid region. Revista Brasileira de Botânica 33: 661-676.

Gomes P, Costa KCC, Rodal MJN \& Alves M (2011) Checklist of Angiosperms from the Pedra Furada Municipal Park, northeastern Brazil. Check List 7: 173-181.

Gomes P \& Sobral-Leite M (2013) Crystalline rock outcrops in the Atlântic Forest of northeastern Brazil: vascular flora, biological spectrum, and invasive species. Brazilian Journal of Botany 36: 111-123.

Hurault J (1963) Recherches sur les inselbergs granitiques nus en Guyane française. Revue de Géomorphologie Dynamique 4: 49-61.

IBGE - Instituto Brasileiro de Geografia e Estatística (2012) Manual técnico da vegetação brasileira. Série Manuais Técnicos em Geociências. 2a ed. IBGE, Rio de Janeiro. 274p.

Ibisch PL, Rauer G, Rudolph D \& Barthlott W (1995) Floristic, biogeographical, and vegetational aspects of Pre-Cambrian rock outcrops (inselbergs) in Eastern Bolivia. Flora 190: 299-314.

INCAPER - Instituto Capixaba de Pesquisa (2016) Assitência técnica e extenção rural. Available at $<$ http://hidrometeorologia.incaper.es.gov.br>. Access on 31 July 2016.

IPNI - International Plant Names Index (2016) Available at $<$ http://www.ipni.org/>. Access on 23 October 2016.

IUCN - International Union for Conservation of Nature (2017) The IUCN Red list of threatened species. Version 2016-2. Available at $<$ http://www. iucnredlist.org>. Access on 8 May 2017.

Kurtz BC \& Araújo DSD (2000) Composição florística e estrutura do componente arbóreo de um trecho de Mata Atlântica na Estação Ecológica Estadual do Paraíso, Cachoeiras de Macacu, Rio de Janeiro, Brasil. Rodriguésia 51: 69-112.

Leme EMC, Fraga CN, Kollmann LJC, Brown GK, Till W, Ribeiro OBC, Machado MC, Monteiro FJS \& Fontana AP (2010) Miscellaneous new species in the Brazilian Bromeliaceae. Rodriguésia 61: 21-67.

Luber J, Amélia CT, Torres F, Christ JA, GuidoniMartins KG, Zanetti M, Hollunder RK, Manhães VC, Zorzanelli JPF, Mendonça ES, Garbin ML \& Carrijo TT (2016) List of angiosperm species in an Atlantic Forest fragment reveals collection gaps in Espírito Santo state, Brazil. Check List 12: 1835.
Medina BMO, Ribeiro KT \& Scarano FR (2006) Plantplant and plant-topography interactions on a rock outcrops at high altitude in Southeastern Brazil. Biotropica 38: 27-34.

Meirelles ST, Pivello VR \& Joly CA (1999) The vegetation of granite rock outcrops in Rio de Janeiro, Brazil, and the need for its protection. Environmental Conservation 26: 10-20.

MMA - Ministério do Meio Ambiente (2002) Avaliação e identificação de áreas e ações prioritárias para conservação, utilização sustentável e repartição dos benefícios da biodiversidade nos biomas brasileiros. MMA/SBF, Brasília. 404p.

Oliveira-Filho AT, Fontes MAL, Viana PL, Valente ASM, Salimena FRG \& Ferreira EN (2013) O mosaico de fitofisionomias do Parque Estadual do Ibitipoca. In: Forzza RC, Neto LM, Salimena FRG \& Zappi D (orgs.) Flora do Parque Estadual do Ibitipoca e seu entorno. UFJF, Juiz de Fora. Pp. 53-93.

Peixoto AL \& Gentry A(1990) Diversidade e composição florística da mata de tabuleiro na Reserva Florestal de Linhares (Espírito Santo, Brasil). Revista Brasileira de Botânica 13: 19-25.

Pereira OJ \& Araujo DSD (2000) Análise florística das restingas dos estados do Espírito Santo e Rio de Janeiro. In: Esteves FA \& Lacerda LD (eds.) Ecologia de restingas e lagoas costeiras. NUPEM/ UFRJ, Rio de Janeiro. Pp. 25-63.

Pereira OJ, Assis AM \& Souza RLD (1998) Vegetação da restinga de Pontal do Ipiranga, município de Linhares (ES). In: Watanabe S (coord.) Anais do IV simpósio de ecossistemas brasileiros. Aciesp, São Paulo. Pp. 117-128.

Pereira OJ \& Zambom O (1998) Composição florística da restinga de Interlagos, Vila Velha(ES). In: Watanabe S (coord.) Anais do IV Simpósio de Ecossistemas Brasileiros. Aciesp, São Paulo. Pp. 129-139.

Peterle PL, Chagas AP, Thomaz LD, Dutra VF \& Valadares RT (2015) Mimosoideae (Leguminosae) do Parque Estadual Paulo César Vinha, Espírito Santo, Brasil. Rodriguésia 66: 245-257.

Porembski S (2000) The invasibility of tropical granite outcrops ('inselbergs') by exotic weeds. Journal of the Royal Society of Western Australia 83: 131-137.

Porembski S (2007) Tropical inselbergs: habitat types, adaptive strategies and diversity patterns. Revista Brasileira de Botânica 30: 579-586.

Porembski S \& Barthlott W (1997) Inselberg vegetation and the biodiversity of granite outcrops. Journal of the Royal Society of Western Australia 80: 193-199.

Porembski, S. \& Barthlott, W. 2000. Granitic and gneissic outcrops (inselbergs) as centers of diversity for desiccation-tolerant vascular plants. Plant Ecology 151: 19-28.

Porembski S, Seine R \& Barthlott W (1997) Inselberg vegetation and the biodiversity of granite outcrops. Journal of the Royal Society of Western Australia 80: 193-199. 
Ratter JA, Bridgewater S \& Ribeiro JF (2003) Analysis of the floristic composition of the Brazilian cerrado vegetation III: comparison of the woody vegetation of 376 areas. Edinburgh Journal of Botany 60 : 57-109.

Raunkiaer C (1934) The life forms of plants and statistical plant geography. Clarendon Press, Oxford. 632p.

Saiter FZ \& Thomaz DL (2014) Revisão da lista de espécies arbóreas do inventário de Thomaz \& Monteiro (1997) na Estação Biológica de Santa Lúcia: o mais importante estudo fitossociológico em florestas montanas do Espírito Santo. Boletim do Museu de Biologia Mello Leitão (Nova Série) 34: 101-128.

Sarnaglia Junior VB, Thomaz LD, \& Guimarães EF (2014) O gênero Peperomia Ruiz \& Pav. na Área de Proteção Ambiental do Mestre Álvaro, Espírito Santo, Brasil. Boletim do Museu de Biologia Mello Leitão (Nova Série) 35: 21-34.

Souza WO, Machado JO, Tognella MMP \& AlvesAraújo A (2016) Checklist de angiospermas do Parque Estadual de Itaúnas, Espírito Santo, Brasil. Rodriguésia 67: 571-581.

Thiers B [continuously updated] Index Herbariorum: a global directory of public herbaria and associated staff. New York Botanical Garden's Virtual Herbarium. Available at <http://sweetgum.nybg. org/science/ih/>. Access on 31 May 2017.

Thomas WW, Jardim JG, Fiaschi P, Neto EM \& Amorim AM (2009) Composição florística e estrutura do componente arbóreo de uma area transicional de Floresta Atlântica no sul da Bahia, Brasil. Revista Brasileira de Botânica 32: 65-78. 
